\title{
Horizontal Zonation of Macrovegetation, Water Properties and Macrofauna in a Littoral Stand of Glyceria aquatica (L.) Wahlb. in a Pond in South Bohemia
}

\author{
by \\ JAN DVoŘÁK \\ Research Institute of Fishery and Hydrobiology, Vodňany, \\ Czechoslovakia
}

\section{INTRODUCTION}

The investigation of the zonation of the macrofauna and several environmental factors in the stand of emergent vegetation in pond Radov (DvoŘ́́k, J. - in print) revealed the gradient of the life conditions (particularly for the summer period) from the open water to the shore. This gradient influenced the quantity (abundance and biomass) of organisms and the formation of animal communities in the locality. The aim of the present study was to obtain some more knowledge of the zonation of the water properties as well as of several biological factors of the littoral emergent pond vegetation along the transection, which ran from the open water to the shore. The object of the study was a locality which was overgrown above all by a single plant species, namely Glyceria aquatica (L.) WAHLB. This species belongs among the most frequent representatives of the pond flora in south Bohemia. The investigation was carried out during the peak development of the stand (July-Sept.) in 1965.

Received March 12th, 1969. 


\section{DESCRIPTION OF THE LOCALITY}

The object under study was the littoral stand of Glyceria aquatica (L.) WAHLB. of the pond Dremliny near the town of Vodñany in south Bohemia (Figs. 1,2). The pond is situated at an altitude of almost $390 \mathrm{~m}$ above the sea level in an open landscape, which is exposed to wind action from the west, in particular from the northwest for the greater part of the year. The stand of Glyceria was situated at the southern shore of the pond. The pond drains an area of about 60 hectares. In 1965, the pond was stocked with 1,130 two years old carp per hectare; the fish production of that year was estimated at $830 \mathrm{~kg}$ per hectare. The pond was eutroficated by purified industrial waste waters from a factory for poultry processing and by town wastes, brought in by the main inflow. Samples were collected at 5 stations $(\mathrm{A}, \mathrm{B}, \mathrm{C}, \mathrm{D}, \mathrm{E})$; these were dislocated along the transection, which ran vertically from the shore to the open pond water (Figs. 1,2).

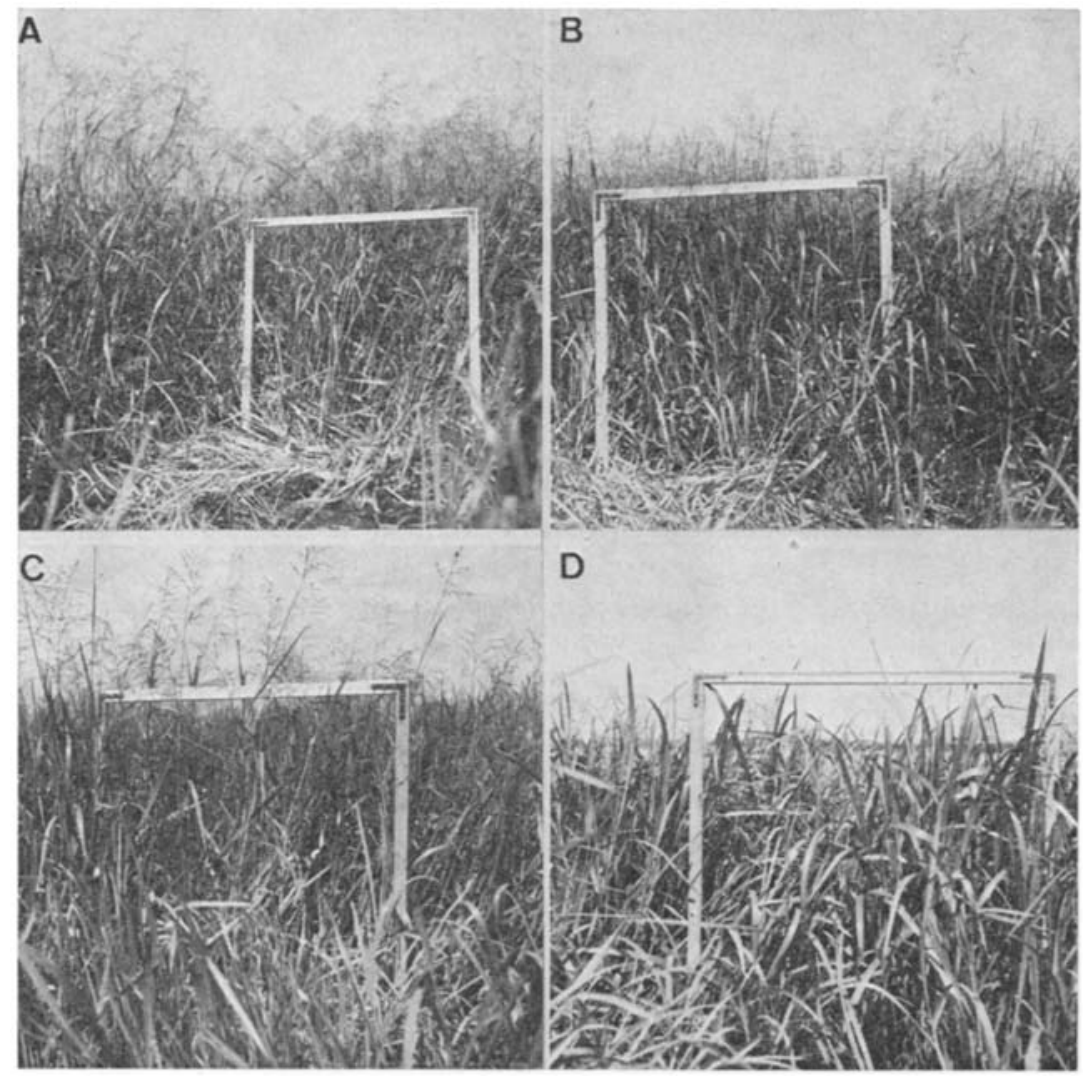

Fig. 1. Views of stations $A, B, C$ and $D$ (frame side $=1 \mathrm{~m}$ ). 

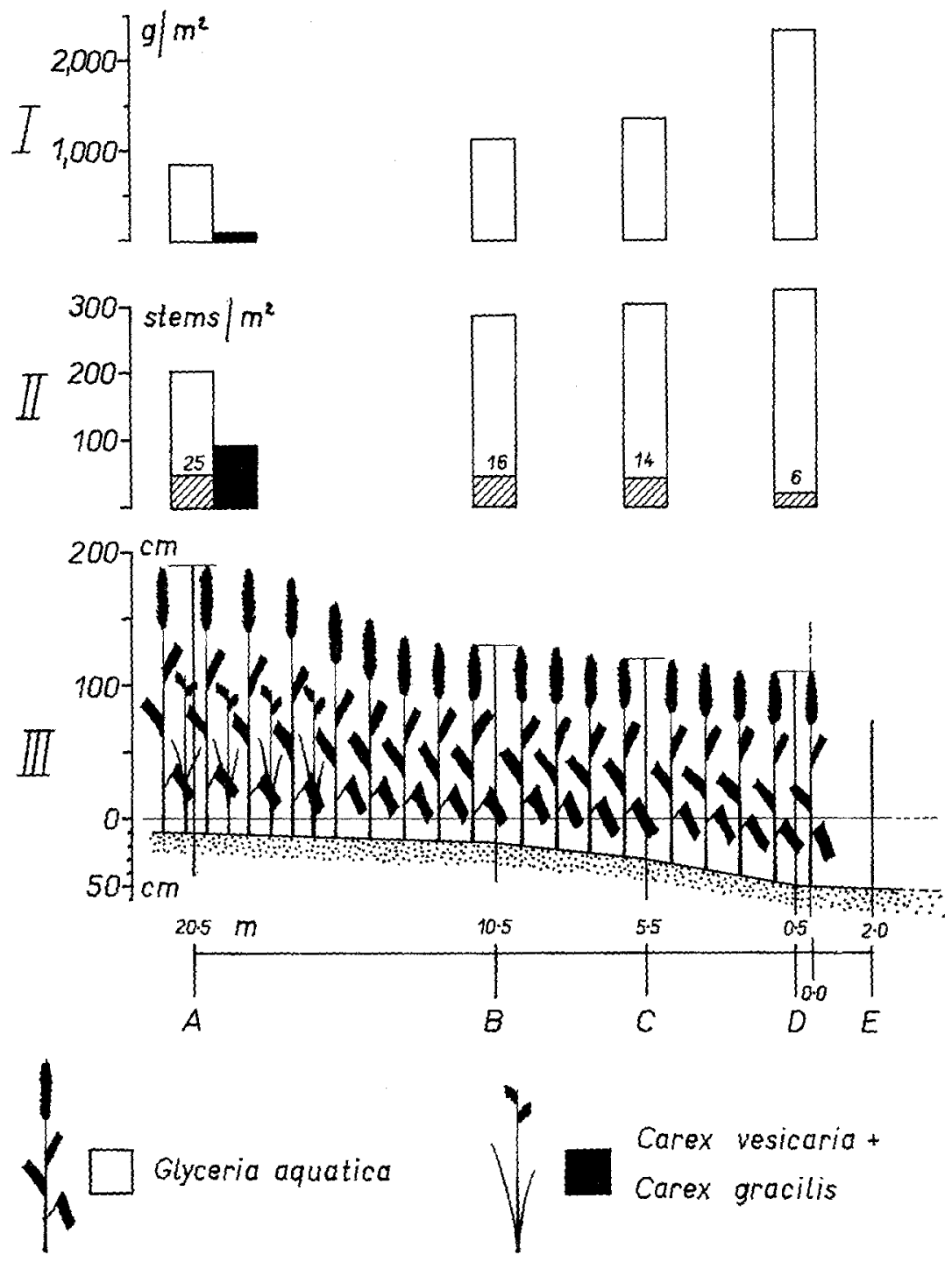

\section{Glyceria aq-fertile stems}

Fig. 2. (I) Production of the above-ground parts of stems of macrovegetation in $\mathrm{g} / \mathrm{m}^{2}$ of dry matter obtained at $105^{\circ} \mathrm{C}$.

(II) Number of stems per $1 \mathrm{~m}^{2}$. The numbers in the columns of the species Glyceria aquatica give the percentage of the fertile stems.

(III) Scheme of the stand. The scales indicate the height of the stand from the water surface and the water depth in $\mathrm{cm}$, as well as the distance of the stations $A, B, C, D$ and $E$ from the boundary line of the stand and the pond water in $\mathrm{m}$ $(0.0=$ boundary line of the stand $)$. 
The stand of vegetation on the locality was not affected by amelioration. Station A contained in addition to Glyceria aquatica specimens of Carex gracilis CurT. and C. vesicaria $\mathrm{L}$. The stations $\mathrm{B}, \mathrm{C}$ and $\mathrm{D}$ were located in a pure stand of Glyceria aquatica, while station $\mathrm{E}$ in the open pond water. The species Lemna minor $\mathrm{L}$. was very rich at the water surface of stations A to D being followed by the species Lemna trisulca L., Ricciocarpus natans (L.) CoRDA, and Riccia cf. fluitans $\mathrm{L}$. The surface water layer at stations $\mathrm{A}$ and $\mathrm{B}$ was divided by the uneveness of the bottom and the ununiformly accumulated plant remains into a dense net of small pools, which assumed a terrestrial character towards the shore. The water layer at stations C and D spread out smoothly. The water level dropped by roughly $5 \mathrm{~cm}$ during the investigation.

\section{MATERIAL AND METHODS}

\section{The factors followed}

The production of macrovegetation, the morphological properties of the stand, the water colour and macrofauna were determined only once during Aug. 16 - Sept. 15, 1965. Water temperature, alkalinity, $\mathrm{pH}$, dissolved oxygen, phytoplancton photosynthesis and respiration were measured 5 times at approximately fortnight intervals during July 7 - Sept. 9, 1965 (except for station C, i.e. 4 times during July 20 - Sept. 9).

\section{Sampling methods and treatment of samples}

Samples for the determination of the water properties, the phytoplancton photosynthesis and respiration were taken from 2 points at each of the stations approximately $5 \mathrm{~cm}$ below the water surface between 3 and 5 o'clock p.m. The sampling device is described in a paper by the author (DvoŘÁk, J. - in print). Water temperature was measured with a mercury thermometer of $0.1^{\circ} \mathrm{C}$ precision. Alkalinity was determined by titrating $0.1 \mathrm{n} \mathrm{HCl}$ with an accuracy of $0.1 \mathrm{mval} / 1$ (using bromphenol-blue as indicator). The $\mathrm{pH}$ value was obtained colorimetrically with an accuracy of $0.1 \mathrm{pH}$. Dissolved oxygen was determined by the Winkler method with an accuracy of $0.01 \mathrm{mg} / 1 \mathrm{O}_{2}$. The water colour was determined by comparing a sample passed through a glass filter (S4 porosity) with the standard solutions of potassium chloroplatinate in Nessler's cylinders with an accuracy of $5 \mathrm{mg} / \mathrm{l} \mathrm{Pt}$ in the range of $0-100 \mathrm{mg} / \mathrm{Pt}$ and with an accuracy of $10 \mathrm{mg} / 1 \mathrm{Pt}$ for values exceeding $100 \mathrm{mg} / 1 \mathrm{Pt}$. The phytoplancton photosynthesis and respiration were determined by the light-anddark-bottle oxygen method; the bottles were suspended at the samp- 
ling stations (approximately 3-10 $\mathrm{cm}$ below the water surface) for a period of 24 hrs.

The morphological properties of the stand were measured by means of a steel-band measure, the height of the stand by projecting the tops of the stems onto the length scale from lateral view. The production of macrophytes (the this-year above-ground parts of plants) was determined during fading by cutting the stems from an area of $2.0 \mathrm{~m}^{2}$ at each of the stations and by drying the material at $105^{\circ} \mathrm{C}$ and weighing it with an accuracy of $1 \mathrm{~g}$. To analyse the plants, 5 sterile and 5 fertile stems were used at each station which were collected during the determination of the production. The material was homogenized and the content of nitrogen was determined by the Kjeldahl method and the ashing was done at $550^{\circ} \mathrm{C}$.

The macrofauna samples were obtained by pulling a net (used for the washing of benthos samples) through the water of the stations. The material obtained was preserved with formalin, determined, counted and weighed. (1,030 specimens were collected at station A, 1,189 at station $\mathrm{B}, 1,139$ at $\mathrm{C}$, and 662 at D). The abundance of individual forms of animals was expressed by the relative frequency scale (HRBÁČEK, J. \& NovotNÁ-Dvo ŘÁKOVÁ, M., 1965):

$$
\begin{array}{ll}
\mathrm{x} & \text { relative frequency under } 1 \% \\
1 & \text { relative frequency of } 1-5 \% \\
2 & \text { relative frequency of } 6-10 \% \\
3 & \text { relative frequency of } 11-20 \% \\
4 & \text { relative frequency of } 21-40 \% \\
5 & \text { relative frequency of } 41-80 \%
\end{array}
$$

\section{Results}

\begin{tabular}{|c|c|c|c|c|c|c|c|c|}
\hline \multirow{5}{*}{$\begin{array}{l}\text { Stations } \\
\text { Percentage } \\
\text { ash in dry } \\
\text { matter } \\
\text { Percentage } \\
\text { nitrogen in } \\
\text { organic matter }\end{array}$} & \multicolumn{4}{|c|}{ Fertile stems } & \multicolumn{4}{|c|}{ Sterile stems } \\
\hline & A & B & C & D & A & B & C & $\mathrm{D}$ \\
\hline & 39 & 4.4 & 4.0 & 46 & 53 & 5.1 & 4.9 & 8.3 \\
\hline & & & & & & & & \\
\hline & 0.4 & 0.6 & 0.5 & 1.0 & 1.4 & 1.1 & 1.2 & 2.7 \\
\hline
\end{tabular}

All results of observations are given in Figs. 2, 3, 4 and in Tabs. I II and III. Values in Figs. 2 and 4 and in the tables were obtained by

TABLE I

Ash content in dry matter and nitrogen content in organic matter of the stems of Glyceria aquatica (L.) WAHLB. 
TABLE II

\begin{tabular}{lcccc}
\hline Stations & A & B & C & D \\
\hline $\begin{array}{l}\text { Average weight } \\
\text { of animals in mg } \\
\begin{array}{l}\text { Percentage share } \\
\text { of predators in } \\
\text { total biomass }\end{array}\end{array}$ & 2.2 & 2.3 & 5.2 & 12.9 \\
\hline
\end{tabular}

TABLE III

List of animals found at stations $A, B, C$, and $D$ and their relative abundance.

$\begin{array}{llll}\text { A } & \text { B } & \text { C } & \text { D }\end{array}$

TURBELlaria

Planaria cf. torva O. F. MÜLL.

$\mathbf{x} \quad \mathbf{x}$

OLIGOCHAETA

Stylaria lacustris LINNÉ

Oligochaeta g. sp.

$\begin{array}{llll}2 & \\ 3 & 1 & 1\end{array}$

HiRUDinEA

Theromyzon tessulatum (O. F. MÜLL.)

Helobdella stagnalis (LINNE)

Glossiphonia heteroclita (LINNÉ)

Erpobdella testacea (SAvIGNY) + sp. juv.

Erpobdella octoculata LiNNÉ

$\begin{array}{cccc} & & \mathrm{x} & \\ \mathrm{x} & \mathrm{x} & \mathrm{x} & 4 \\ \mathrm{x} & & 1 & 1 \\ & & \mathrm{x} & \mathrm{x} \\ & & & 1\end{array}$

Mollusca

Aplexa hypnorum (LINNÉ)

Lymnaea palustris (O. F. MÜLL.)

Radix sp. juv.

Bathyomphalus contortus (LINNÉ)

Gyraulus albus (O. F. MǘL.)

Armiger crista (LINNÉ)

Segmentina nitida (O. F. MÜLL.)

Acroloxus lacustris (LINNÉ)

3

$\mathrm{x} \quad \mathrm{x}$

$1 \quad 2$

1

$1 \quad \mathrm{x}-\mathrm{x}$

$4 \quad 4 \quad 3$

1

Pisidium cf. casertanum (PoLI)

AraneaE

Argyroneta aquatica (LINNÉ)

$\begin{array}{llll}\mathrm{x} & \mathrm{x} & 1\end{array}$

HYDRACARINA

Hydracarina g. sp.

$\mathbf{x}$

$\mathbf{x}$

EPHEMEROPTERA

Cloëon dipterum (LINNÉ)

Caenis cf. horraria (LINNÉ) 


\begin{tabular}{|c|c|c|c|c|}
\hline & A & $\mathrm{B}$ & C & $\mathrm{D}$ \\
\hline \multicolumn{5}{|l|}{ HETEROPTERA } \\
\hline Gerris odontogaster (ZETT.) & & & & $x$ \\
\hline Nepa cinerea LINNÉ & & & & $x$ \\
\hline Ilyocoris cimicoides (LINNÉ) & & & & 1 \\
\hline Plea leachi MACGREG. & & & & $\mathrm{x}$ \\
\hline Notonecta glauca LINNÉ & & & & 1 \\
\hline Corixa linnei (FIEB.) & & & & 2 \\
\hline Corixa falleni (FIEB.) & & & & $\mathrm{x}$ \\
\hline Corixa striata (LINNÉ) & & & & $\mathrm{x}$ \\
\hline Corixa nymph. & & & & $\mathrm{x}$ \\
\hline
\end{tabular}

COLEOPTERA-IMAG.

Hygrotus inaequalis $\mathrm{F}$.

Coelambus impressopunctatus SCHALI.

Hydroporus cf. obscurus STRM.

Noterus crassicornis MÜLL.

Laccophilus obscurus PANZ.

Rhantus notatus $\mathrm{F}$.

Graphoderes cinereus LINNÉ

Helophorus cf. griseus HRBST.

Spercheus emarginatus ScHALl.

Berosus spinosus STEV.

Philydrus minutus $\mathrm{F}$.

Philydrus quadripunctatus HRBsT.

Philydrus testaceus $\mathrm{F}$.

Laccobius minutus LINNÉ

$\begin{array}{cccc} & & & \mathrm{x} \\ \mathrm{x} & \mathrm{x} & \mathrm{x} & \mathrm{x} \\ 1 & \mathrm{x} & 1 & 2 \\ & & \mathrm{x} & \mathrm{x} \\ & & & \mathrm{x} \\ \mathrm{x} & \mathrm{x} & & \mathrm{x} \\ & \mathrm{x} & \mathrm{x} & \\ \mathbf{x} & \mathrm{x} & \mathrm{x} \\ 1 & \mathrm{x} & \mathrm{x} & \mathrm{x} \\ \mathbf{x} & & \mathrm{x} & \mathrm{x} \\ \mathbf{x} & \mathrm{x} & & 1 \\ \mathrm{x} & \mathrm{x} & & \\ \mathrm{x} & & & \mathrm{x} \\ & \mathrm{x} & & \mathrm{x}\end{array}$

Limnebius truncatulus THомs.

Coelostoma orbiculare $\mathrm{F}$.

Dicyrtocercyon ustulatus PREYssL.

Cercyon cf. convexiusculus SYEPH.

ColEoptera-laRv.

Hydroporini

Colymbetini

Philydrus

Helodidae

\begin{tabular}{cccc}
$\mathbf{x}$ & $\mathbf{x}$ & $\mathbf{x}$ & $\mathbf{x}$ \\
$\mathbf{x}$ & & $\mathbf{x}$ & \\
$\mathbf{x}$ & $\mathbf{x}$ & & $\mathbf{x}$ \\
\hline
\end{tabular}

LEPIDOPTERA

Cataclysta lemnata LINNÉ

Lepidoptera g. sp.

$\begin{array}{lll} & \mathrm{x} \\ \mathrm{x} & \mathrm{x}\end{array}$

\section{Diptera}

Psychoda

Paradixa

Chaoborus cf. crystallinus DEGEER

Anopheles maculipennis MEIGEN

Theobaldia annulata (SCHRANK)

Culex pipiens LINNÉ

$\begin{array}{llll} & \mathrm{x} & & \\ 1 & 1 & 1 & 1 \\ & & & 2 \\ 1 & 3 & 5 & 1 \\ 2 & 4 & 2 & 2\end{array}$


TABLE III (Continued)

\begin{tabular}{|c|c|c|c|c|}
\hline & A & B & $\mathrm{C}$ & $\mathrm{D}$ \\
\hline Ablabesmyia gr. Falcigera & 1 & 1 & 1 & $\mathrm{x}$ \\
\hline Eucricotopus gr. Silvestris & & & & $\mathrm{x}$ \\
\hline Limnophyes & 1 & 1 & $\mathbf{x}$ & $\mathrm{x}$ \\
\hline Metriocnemus & 1 & 1 & 1 & 1 \\
\hline Smittia & & $\mathbf{x}$ & & \\
\hline Corynoneura & $\mathrm{x}$ & $\mathbf{x}$ & & \\
\hline Chironomus gr. Plumosus & 1 & $\mathrm{x}$ & $\mathbf{x}$ & \\
\hline Phytotendipes gr. Gripekoveni & & & & 1 \\
\hline Endochironomus gr. Abranchius & $\mathrm{x}$ & $\mathrm{x}$ & & $\mathrm{x}$ \\
\hline Polypedilum gr. Nubeculosum & $\mathrm{x}$ & $\mathrm{x}$ & & $\mathrm{x}$ \\
\hline Zavrelia & $\mathrm{x}$ & & $\mathbf{x}$ & $\mathrm{x}$ \\
\hline Ceratopogonidae vermiformes & 1 & 1 & & \\
\hline Forcypomyia & $\mathrm{x}$ & $\mathrm{x}$ & & \\
\hline Eristalis & $\mathrm{x}$ & $\mathrm{x}$ & $\mathbf{x}$ & $\mathbf{x}$ \\
\hline Tabanidae & $\mathrm{x}$ & & $\mathbf{x}$ & $\mathrm{x}$ \\
\hline Musidora? & $\mathrm{x}$ & $\mathbf{x}$ & & \\
\hline Tetanocerinae (Hydroneura) & & & $\mathbf{x}$ & \\
\hline Ulidiidae (Euxesta) & & $\mathrm{x}$ & & \\
\hline Diptera varia & $\mathrm{x}$ & $\mathbf{x}$ & $\mathbf{x}$ & \\
\hline
\end{tabular}

one-time collections and measurements; values given in Fig. 3 (except for the water colour) are the averages of all determinations for the whole period of investigation.

\section{Water properties (Fig. 3)}

From station $\mathrm{A}$ towards station $\mathrm{E}$ there was a gradual increase in water temperature, alkalinity, $\mathrm{pH}$ and dissolved oxygen; particularly in the two last mentioned factors there was a conspicuous increase in the transition from the stand towards the open pond water. In contrast to all these factors, the intensity of the water colour decreased from station $\mathrm{A}$ towards station $\mathrm{E}$.

\section{Phytoplancton photosynthesis and respiration (Fig. 3)}

The values of photosynthesis were very low without conspicuous deviations at the stations inside the stand (A to D), but they suddenly increased in the open pond water. The average value at station $\mathrm{D}$ was only $4.3 \%$ of that at station E. In contrast to photosynthesis, respiration exhibited, despite some deviations of minor importance, fairly balanced values.

Macrovegetation (Fig. 1, 2, Tab. I)

The stand of Glyceria aquatica changed from the shore to the open pond water in the majority of the properties studied. The species of 

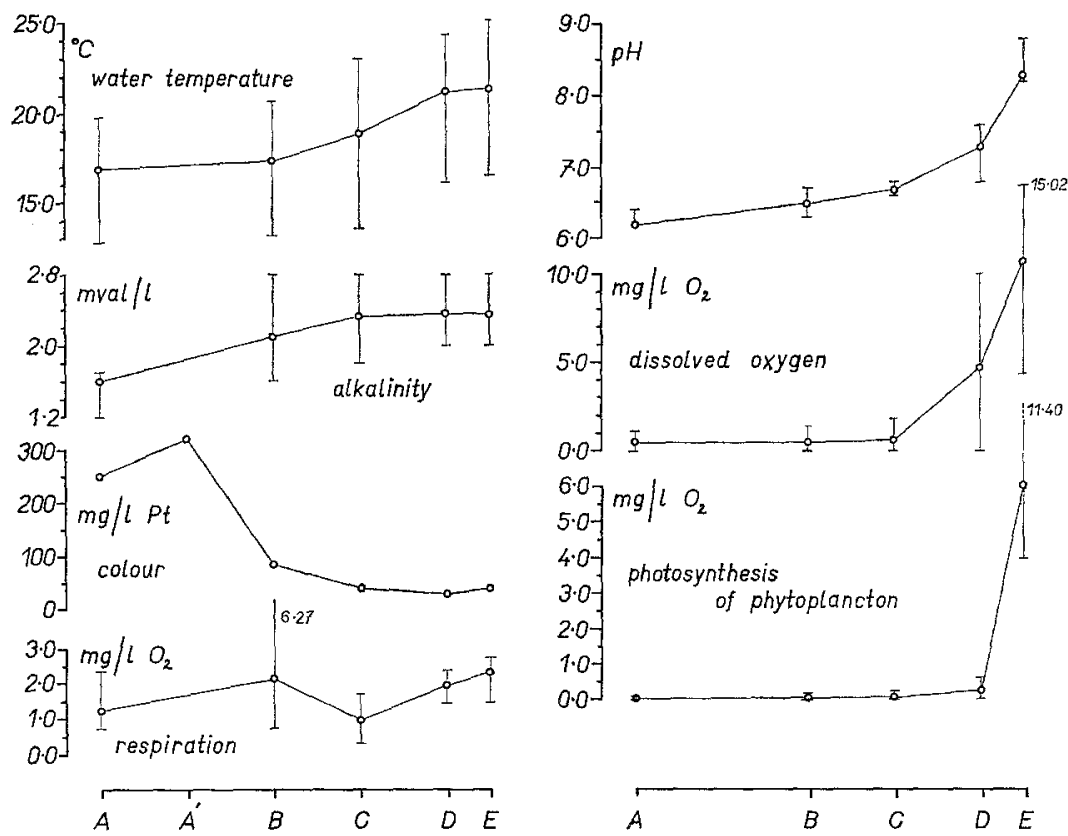

Fig. 3. Average values and the range of the values of the water properties, phytoplancton photosynthesis and respiration for the whole studied period at stations $A, B, C, D$ and $E$.

the genus Carex were limited to the smallest water depth quite near the shore (station A). Differences in the appearance of the stand at individual stations are apparent from Figs. 1 and 2.

The height of the stand of $G$. aquatica, measured from the water surface, decreased gradually from station A to station D. However, there were no substantial differences, except for station $A$, if the height of the stand was measured from the bottom (Fig. 2 III).

The number of the stems of G. aquatica per unit of area increased slightly from station $\mathrm{A}$ to $\mathrm{D}$ along with the simultaneous decrease in the absolute and relative numbers of fertile stems (Fig. 2 II). When the fertile stems at stations $A$ and $B$ had shed their blossoms, earing was observed in several stems at $C$ and $D$.

In accordance with the increase in the total number of stems, the production of $G$. aquatica also increased; a particularly high value was at station $\mathrm{D}$ as compared with the other stations near the shore (Fig. 2 I). The plants of this station were thicker and their colour was a dark green, while at stations $A$ to $C$ they were slender and their colour was a light-green. Table I confirms that the plants at station $\mathrm{D}$ were of a different character as compared with those at stations $A, B$ and $C$. 
Macrofauna (Fig. 4, Tabs. II and III)

At stations A, B and C, Mollusca (above all Segmentina nitida) and culicid larvae (Theobaldia annulata and Culex pipiens) were most abundant while at station D there prevailed leeches (Helobdella stagnalis), Heteroptera (Corixa linnei, Ilyocoris cimicoides, Notonecta glauca) and of the other animals Stylaria lacustris and Chaoborus cf. crystallinus. Some animals were found only at one station being absent at the other stations, e.g. at station A Aplexa hypnorum, while at station D all species of Heteroptera, Chaoborus cf. crystallinus and Phytotendipes Gripekoveni. Some animals, however, occurred
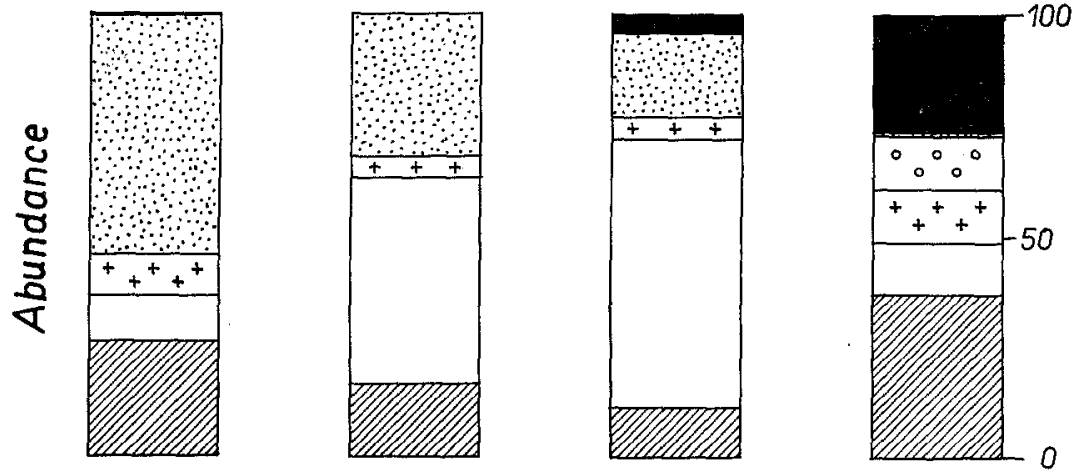

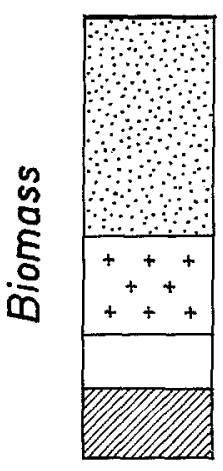

$A$

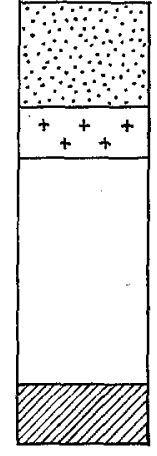

$B$

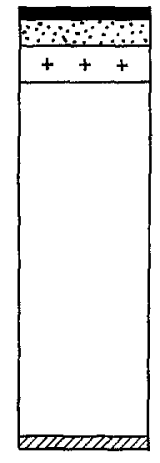

C

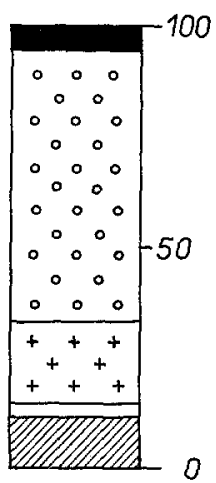

$D$

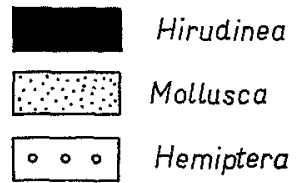

+++ Coleoptera

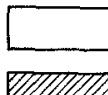

Culicinae

Other animals

Fig. 4. The percentage share of the most important groups of animals in total macrofauna at stations $\mathrm{A}, \mathrm{B}, \mathrm{C}$ and $\mathrm{D}$. 
fairly uniformly at all the stations, e.g. imagos of Noterus crassicornis, larvae of Paradixa, Ablabesmyia Falcigera, and of semi-terrestrial chironomid larvae, Limnophyes and Metriocnemus.

Station D near the boundary line between the stand and the open pond water differed markedly in the macrofauna composition from all the stations inside the stand which despite certain differences were substantially similar. The difference in the macrofauna at station D as compared with the other stations is indicated by Tab. II which points above all to large predators.

\section{Discussion}

It may be assumed that it is above all the presence of plants which influences the environmental conditions of the stand making them different from those of the open pond. However, the stand of Glyceria aquatica was not a homogeneous factor in itself. The initial phase of the stand at station $D$ is well apparent; the whole appearance of the plants, the prevalance of vegetative stems, the high production and the analyses of the stems at this station point to a very good nutritional state of the vegetation, spreading over the bottom, which was probably rich in nutrients. The eutrophication of the pond by waste waters might contribute in this respect. The Kjeldahl nitrogen (in water and nannoseston) in the pond water ranged from 1.3 to $1.8 \mathrm{mg} / 1 \mathrm{~N}$ from April to early July, increasing to 2.3 up to $4.2 \mathrm{mg} / 1$ N from late July onwards (Dvo Ř́́k, J. \& Poštolková, M., 1967). This indicates a considerable supply of nutrients of allochtonous origin. The stand at the stations inside the locality, in particular at stations $A$ and $B$, was at a balanced state. Station $\mathrm{C}$ though had a transitory character.

The most conspicuous differences among the stations were found in dissolved oxygen and $\mathrm{pH}$. The decrease in the values in both these factors closely behind the boundary line of the stand points to their correlation with phytoplancton photosynthesis (Fig. 3). Neither diffusion from the air, nor the photosynthesis of the floating plants or periphyton succeeded to make up for the oxygen that was consumed by decaying processes. The conspicuous decrease in phytoplancton photosynthesis inside the stand may be explained above all by the shading of the water by plants; phytoplancton, however, surely penetrated to station $\mathrm{D}$. The negligible differences in alkalinity, temperature and the water colour between stations $\mathrm{E}$ and $\mathrm{D}$ give evidence of a good contact between the water behind the boundary line of the stand and the open pond water (possibility of mixing on windy days). 
The decrease of water temperature from, the open pond water towards the shore may be explained by an insufficient warming up of the water owing to the shading by vegetation and the isolation from the open pond water. Very shallow parts inside the stand had always cooler water as compared with the substantially deeper open water of the pond. The intense colouration of water at the additionally introduced station $\mathrm{A}^{1}$ shows that the water colour inside the stand was independent on the presence of Carex.

The stations inside the stand (in particular A and B) may be characterized by low temperature and $\mathrm{pH}$ lower then 7 , a very low oxygen content and a high concentration of humic substances in the water (intense water colour). The most abundant animals in this part of the pond were Aplexa hypnorum, Segmentina nitida, Theobaldia annulata, and Culex pipiens. These are small organisms which respire atmospheric oxygen; they occur in large numbers in periodical dead waters. Near the boundary line of the stand and the pelagial (station D), there was deeper but warmer water which had an alcalic reaction $(\mathrm{pH})$ as compared with the water inside the stand; the oxygen content was higher, while the content of humic substances was lower. The larger living space enabled the occurrence of large animals (Ilyocoris cimicoides, Notonecta glauca, Rhantus notatus, Graphoderes cinereus). Those species were abundant which respire atmospheric oxygen (Hemiptera, Coleoptera), but dissolved oxygen, too (Hirudinea). Conspicuous number of predators points to the great feeding chance. Disproportion in the biomass ratio of predatory and non-predatory macrofauna at station D (Tab. II, Fig. 4) was probably brought to an equilibrium by preying on animals from other sources, e.g. the zooplancton from the pelagial.

Summer zonation of the life conditions and the animals inside the stands with a single water-plant species is reported e.g. in the literature dealing with Phragmites communis Trin. (MeschKat, 1934), Stratiotes aloides L. (Geelen, Heide, 1968, and Higler 1968). The author observed this zonation in the ponds of south Bohemia in the majority of the studied littoral stands of Glyceria aquatica and the species of the genus Carex (unpublished data). The character of the localities under study shows that a conspicuous zonation of the life conditions and the fauna may be expected above all in stands of emergent vegetation or in such of the Stratiotes type, forming a natural transition of the water body to the terrestrial littoral region. Localities of this character belong mostly to the sheltered or separate type of littoral (RYBAK, M., 1964). 
The littoral stand of Glyceria aquatica (L.) WAHLB. under study was not a homogeneous living environment. In most of the factors studied there was a gradient, which led from the open pond water to the shore. As to the growth properties of Glyceria, this phenomenon may be explained by the various age of the stand and the trophic state of the environment. The gradient of the water properties may be explained by the combined effect of different isolation of water from the open pond, shading by vegetation, and decomposition of plant remains. On the basis of these factors it is possible to differentiate the part of the stand under the influence of the open pond (station D) from the isolated part (A and B). Between both parts there were transitions in several factors (stacion C). The part of the stand, which was influenced by the open pond water, had more favourable living conditions as compared with the isolate part, which was inhabited by different species of animals (macrofauna).

\section{ZUSAMMENFASSUNG}

Der studierte Uferpflanzenbestand von Glyceria aquatica (L.) WAHLB. (Fig. 1, 2) war kein homogenes Lebensmilieu. Beim Großteil der untersuchten Faktoren wurde ein Gradient in der Richtung freies Wasser - Ufer festgestellt (Fig. 1, 2, 3). Bei den Eigenschaften des Wachstums von Glyceria kann diese Erscheinung durch verschiedene Alter des Geleges und durch trophische Einflüsse des Milieus erklärt werden. Der Gradient der Eigenschaften des Wassers kann durch gemeinsame Einflüsse der verschiedenen Stufen der Isolation des Wassers in dem Gelege von dem Pelagial des Teiches, durch Beschattung mit Vegetation und Zersetzung der Pflanzenreste erklärt werden. Auf Grund dieser Tatsachen kann man einen Teil des Pflanzenbestandes, der durch den Teich beeinflußt ist (Standort D), von dem isolierten Teil (Standort A und B) unterscheiden. Zwischen beiden wurde dann bei einigen Faktoren ein Übergang gefunden (Standort C). Der Teil des Pflanzenbestandes, der durch den Teich beeinflußt war, hatte bessere Lebensbedingungen als der isolierte Teil und war mit unterschiedlichen Tierarten besiedelt (Fig. 4, Tab. III). 


\section{REFERENCES}

DVoŘÁ, J. \& PošTolkovÁ, M. - 1967 - Využití odpadních vod potravinářského průmyslu pro chov ryb $\mathrm{v}$ rybnícich (Utilization of wastes from alimentary industry in the breeding of fish in ponds). Final report of a research task, Fisheries Research Institute, 34 pp., 13 figs., 4 tables; Vodñany (in Czech).

DvořÁk, J. (in print). A quantitative study on the macrofauna of stands of emergent vegetation in a carp pond in south-west Bohemia (in English with Czech. summary).

Geelen, J. F. M. \& Heide, J. v.D. - 1968 - Microfauna van de Venematen. Med. Hydrobiol. Ver. 2, 2: 53-56 (in Dutch).

HigLeR, L. W. G. - 1968 - Kokerjuffers (Trichoptera) in een verlandingszone van de Venematen (Caddis larvae in a Stratiotes-vegetation in the Venematen). Ibid: 57-65 (in Dutch with English summary).

HRBÁČEK, J. \& NovOTNÁ-DvoŘÁKovÁ, M. - 1965 - Plankton of four backwaters related to their size and fish stock. Rozpravy Československé akademie věd. Řada matematických a přirodních věd, $75,13,64$ pp.; Praha (in English with Czech summary).

Meschikat, A. - 1934 - Der Bewuchs in den Röhrichten des Plattensees. Arch. Hydrobiol., XXVII: 436-517 (in German).

RYBAK, M., RYBAK, J. I. \& TARWID, K. - 1964 - Differences in Crustacea plankton based on the morphological character of the littoral of the lakes. Ekologia Polska-seria A, XII, 11: 159-172 (in English with Polish summary). 